\title{
Erratum to: Synthesis and evaluation of mefway analogs as ligands for serotonin $5 \mathrm{HT}_{1 \mathrm{~A}}$ receptors
}

\author{
Joanne P. Thio ${ }^{1}$ Christopher Liang ${ }^{1} \cdot$ Alisha K. Bajwa $^{1}$. \\ Dustin W. Wooten ${ }^{2} \cdot$ Bradley T. Christian $^{2} \cdot$ Jogeshwar Mukherjee $^{1}$
}

Published online: 29 April 2015

(c) Springer Science+Business Media New York 2015

Erratum to: Med Chem Res (2015) 24:1480-1486

DOI 10.1007/s00044-014-1238-z

The authors would like to correct an error in Fig. 4 (cyclohexyl ketone shown instead of cyclohexyl ester, in structures 11, 12, 13) of the original publication. The corrected Fig. 4 is published with this erratum.

The online version of the original article can be found under doi:10.1007/s00044-014-1238-z.

Jogeshwar Mukherjee

j.mukherjee@uci.edu

1 Preclinical Imaging, B138 Medical Sciences, Department of Radiological Sciences, University of California, Irvine, CA 92697-5000, USA

2 Department of Medical Physics, University of WisconsinMadison, Madison, WI 53705, USA 
Fig. 4 Synthesis scheme of Mefway. Starting with the conversion of the carboxylic acids (11) to the corresponding cyclohexanoyl chlorides (12), the amine WAY-100634 (7) was converted to the corresponding carboxamides (13). Reduction of the carboxylic acid esters with lithium aluminum hydride $\left(\mathrm{LiAlH}_{4}\right)$ gave the corresponding alcohols (14) which were subsequently fluorinated with DAST to provide 4-Mefway (9) and 3-Mefway (10)

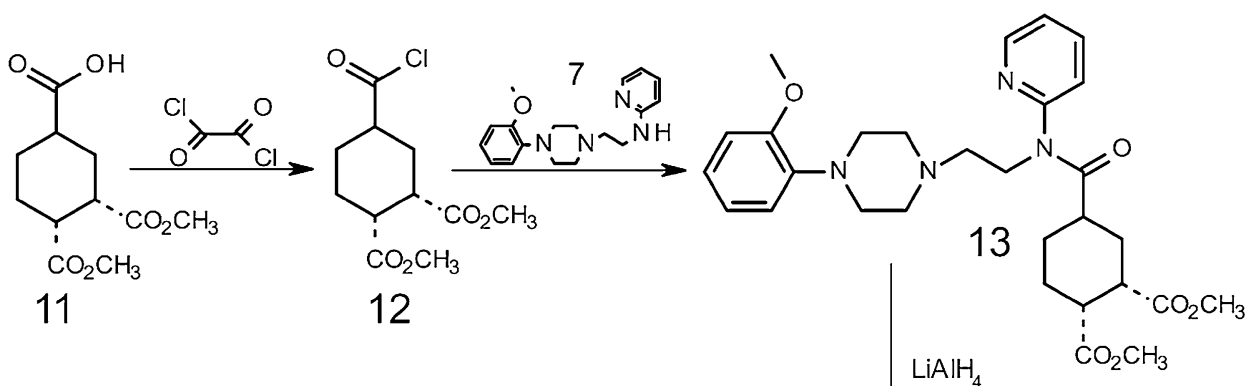<smiles>COc1ccccc1N1CCN(CCN(C(=O)C2CCC(C)C(CF)C2)c2ccccn2)CC1</smiles><smiles>COc1ccccc1N1CCN(CCN(C(=O)C2CC[C@@H](CO)[C@H](CO)C2)c2ccccn2)CC1</smiles> 